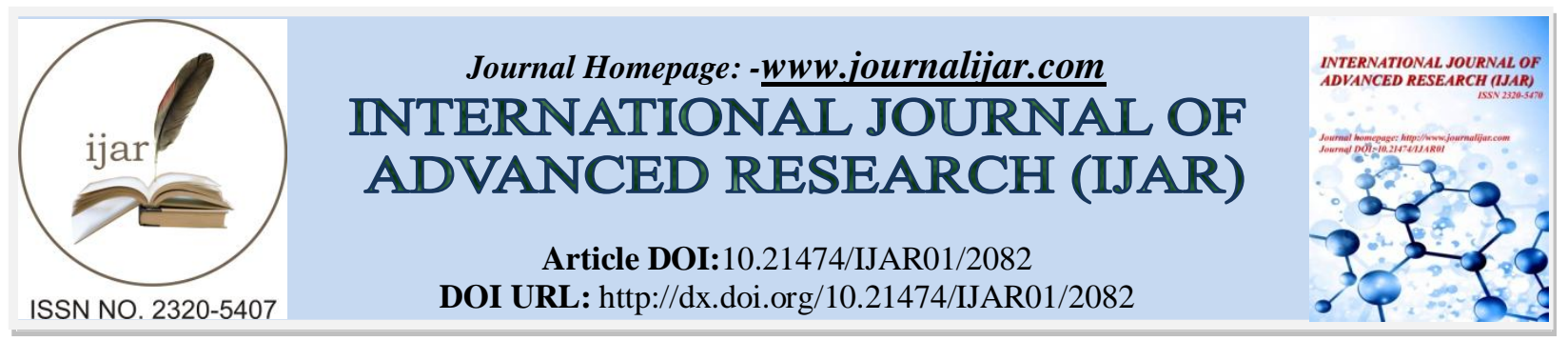

RESEARCH ARTICLE

\title{
STUDIES ON PHYTOPLANKTON RELATED DIVERSITY INDEX OF RIVER SHARDA(UTTARAKHAND).
}

Hem Chandra Upadhyay.

Department of Zoology, R. H. Govt. P.G. College Kashipur, Kumaun university, Uttarakhand.

\section{Manuscript Info}

Manuscript History

Received: 24 September 2016

Final Accepted: 26 October 2016

Published: November 2016

Key words: -

Phytoplankton,Sharda River,Diversity

index, Simpson's dominance index.

\section{Abstract}

Phytoplankton are an integral component of the aquatic ecosystem. Being at the base of an aquatic food chain, these are responsible for almost all the primary production altered in any aquatic ecosystem. The numerical relationship among species, their communities, population often provide a better and reliable detection of pollution with compare to a single species. In the present investigation phytoplanktonic species composition, Shannon-Weiner information function of diversity and Simpson's dominance index was computed.

Copy Right, IJAR, 2016,. All rights reserved.

\section{Introduction: -}

Phytoplankton are minute, chlorophyll bearing organism, occupies the lowest level in aquatic food chain pyramid system. They form the base of a grazing food chain and work as primary producers by trapping solar energy in the aquatic ecosystems. These are the major source of dissolved oxygen in the water bodies and are a good indicator of water quality (Wetzel 1975, 2001;Lynch 1980;Pathani et. al, 2002).Presence of plankton in any aquatic media directly affects the productivity of that aquatic system.Phytoplankton are very sensitive to changes in these environment and affects dissolved oxygen levels, nutrient concentrations, light levels, and zooplankton biomass.Plankton composition and diversity estimationhave often been utilized to evaluate the overall health of riverine ecosystem. The species diversity index is a quantitative measure that help in evaluation of how much diverse theparticular aquatic community. It also indicates the number and individuals of different species present in an ecosystem at a specific time and in a unit space. Shannon-Weiner diversity index is the best indicator of water quality categorization.Recentobservations on Shannon-Weiner diversity index have been reported by several researchers such as Huang et. al, (2004), Zalocar de Domitrovic et. al, (2007),Desai et. al, (2008) etc. Plankton population and their distribution are greatly affected by pollution. Therefore, the magnitude and dynamic of phytoplankton population has become a very effective tool to assess river health. Thus the attempts have been made to assess the pollution level in the Sharda River by computing Shannon-Weiner diversity index and Simpson's dominance index.

\section{Material and methods: -}

The qualitative and quantitative estimation of phytoplankton community was done by filtering about 50 litres of water through the plankton net. Then the filtrate was collected and counting was done by a method using SedgwickRafter counting cell.Standard books and manuals were followed to identify the phytoplankton taxa (Pennak 1958; Edmondson, 1959; Fitter and Manuel, 1986; APHA 1999). The data were collected for a period of one year at three sampling points $\mathrm{S} 1\left(29^{\circ} 08^{\prime} 13.72^{\prime \prime} \mathrm{N}, 80^{\circ} 10^{\prime} 56.73^{\prime \prime} \mathrm{E}\right), \mathrm{S} 2\left(29^{\circ} 06^{\prime} 45.10^{\prime \prime} \mathrm{N}, 80^{\circ} 09^{\prime} 19.36^{\prime \prime} \mathrm{E}\right)$ and $\mathrm{S} 3\left(29^{\circ} 04^{\prime} 39.06^{\prime \prime} \mathrm{N}\right.$, $80^{\circ} 07^{\prime} 07.10^{\prime \prime E}$ ) from January 2012 to December 2012 (fig.1.2). 


\section{Shannon-Wiener species diversity index $\left({ }^{-} \mathbf{H}\right)$ : -}

Diversity index was determined using Shannon-Wiener diversity index, which is:

$\bar{H}=-\sum_{i=1}^{S} P i \log _{2} P i$,

\section{Concentration of dominance (Simpson's index):-}

It was calculated by the following formula.

$\mathrm{C}=\sum_{i=1}^{s}(P i)^{2}$

where: $P i=$ proportion of the abundance of species

Population density: -

No. of phytoplankton $\left(\right.$ units/l) $=\frac{(\mathrm{a} \times 1,000) \mathrm{C}}{\mathrm{L}}$

where:

$\mathrm{a}=$ average no. of plankton in all counts in counting unit of an ml capacity

$\mathrm{C}=$ volume of original concentrate in $\mathrm{ml}$

$\mathrm{L}=$ volume of original water filtered expressed in litres

Table 1.1: -List of phytoplankton taxa collected from Sharda River during the study period (January 2012 to December 2012).

\begin{tabular}{|l|l|l|l|}
\hline S. No. & Phytoplankton taxa & S. No. & Phytoplankton taxa \\
\hline & Chlorophyceae & & Bacillariophyceae \\
\hline 1. & Actinastrumsp. & 1. & Asterionellasp. \\
\hline 2. & Ankistrodesmusfalacatus & 2. & Cyclotellasp. \\
\hline 3. & Chlamydomonas sp. & 3. & Cymbellasp. \\
\hline 4. & Chlorella sp. & 4. & Diatoma sp. \\
\hline 5. & Cladophorasp. & 5. & Fragillariacapucina \\
\hline 6. & Closteridiumsp. & 6. & Gomphonemaintericatum \\
\hline 7. & Closteriumsp. & 7. & Navicullasp. \\
\hline 8. & Coelastrummicroporum & 8. & Synedra sp. \\
\hline 9. & Cosmariumsp. & 9. & Tabellaria fenestrate \\
\hline 10. & Desmidiumsp. & & Cyanophyceae \\
\hline 11. & Gonatozygonsp. & 1. & Merismopediasp. \\
\hline 12. & Mougeotiasp. & 2. & Microcystis sp. \\
\hline 13. & Pediastrumsp. & 3. & Oscillatoriasp. \\
\hline 14. & Spirogyra sp. & 4. & Spirulina sp. \\
\hline 15. & Volvoxsp. & & Xanthophyceae \\
\hline 16. & Zygnemasp. & 1. & Tribonemasp. \\
\hline & & & Total number of taxa 30 \\
\hline
\end{tabular}


Table 1.2: -Seasonal variation in total number of species belonging to different phytoplankton groups collected during the study period (January 2012 to December 2012).

\begin{tabular}{|l|l|l|l|l|l|}
\hline Groups & Chlorophyceae & Bacillariohyceae & Cyanophyceae & Xanthophyceae & Total \\
\hline Jan 2012 & 7 & 4 & 1 & 0 & 12 \\
\hline Feb & 5 & 5 & 2 & 0 & 12 \\
\hline Mar & 6 & 5 & 3 & 0 & 14 \\
\hline Apr & 6 & 4 & 2 & 0 & 12 \\
\hline May & 6 & 3 & 2 & 0 & 11 \\
\hline Jun & 3 & 4 & 2 & 0 & 9 \\
\hline Jul & 3 & 3 & 2 & 0 & 8 \\
\hline Aug & 5 & 3 & 3 & 0 & 11 \\
\hline Sep & 7 & 3 & 2 & 1 & 13 \\
\hline Oct & 5 & 4 & 2 & 1 & 12 \\
\hline Nov & 9 & 4 & 2 & 0 & 15 \\
\hline Dec & 7 & 5 & 2 & 0 & 14 \\
\hline
\end{tabular}

Table 1.3: -Total Estimation of Composition of different groups of Phytoplankton in Units/liter of Sharda River Year-2012.

\begin{tabular}{|l|l|l|l|l|l|}
\hline Months & Chlorophyceae & Bacillariophyceae & Cyanophyceae & Xanthophyceae & Total \\
\hline Jan 2012 & 186 & 160 & 50 & 0 & 396 \\
\hline Feb & 203 & 197 & 98 & 0 & 498 \\
\hline Mar & 210 & 220 & 125 & 0 & 555 \\
\hline Apr & 348 & 232 & 137 & 0 & 717 \\
\hline May & 310 & 191 & 135 & 0 & 636 \\
\hline Jun & 190 & 189 & 128 & 0 & 507 \\
\hline Jul & 131 & 88 & 62 & 0 & 311 \\
\hline Aug & 83 & 53 & 57 & 0 & 202 \\
\hline Sep & 124 & 105 & 51 & 15 & 301 \\
\hline Oct & 115 & 68 & 20 & 331 \\
\hline Nov & 208 & 118 & 53 & 0 & 394 \\
\hline Dec & 173 & 146 & & 0 & 372 \\
\hline
\end{tabular}

Fig 1.1: - Seasonal variation in Shannon-Weiner diversity index and concentration of dominance of phytoplankton in Sharda River from study period (January 2012 to December 2012)

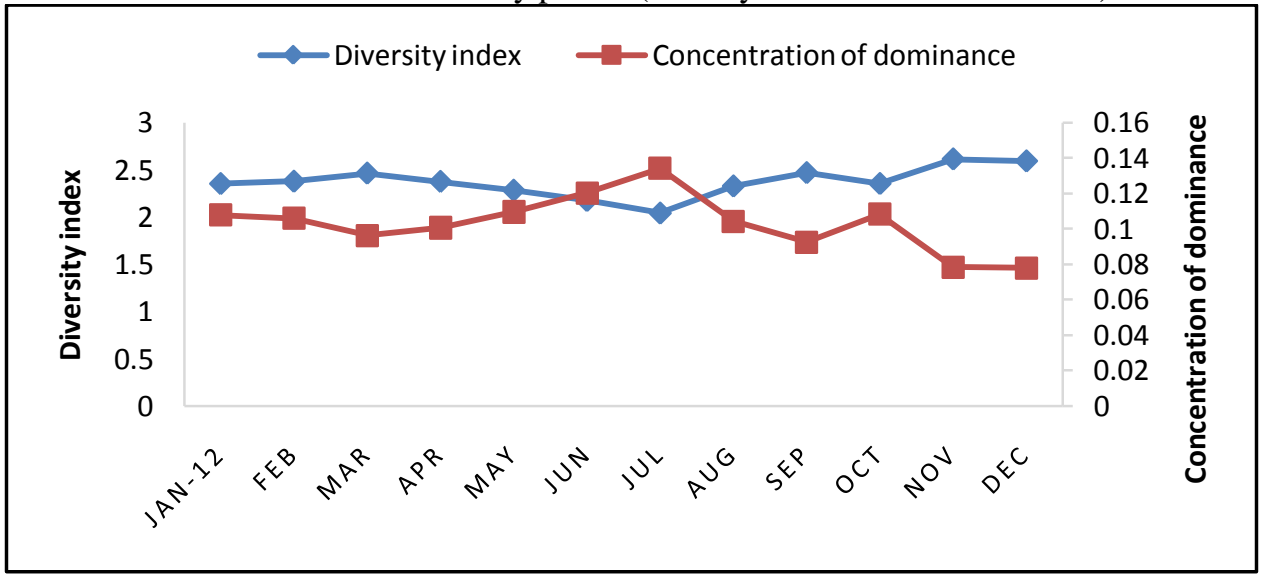

\section{Results and Discussion: -}

During the entire study period of the present investigation, thirty (30) different phytoplanktonic taxa were collected in collection Table (1.1). Of these 30 species, maximum number of species were contributed by the group Chlorophyceae. A maximum number of the Chlorophycean taxa were obtained in the month of November (9). The 
second dominant group in terms of species composition was Bacillariophyceae (5). Characteristically, maximum number of species of this group were collected in the months of March, February and DecemberTable (1.2).In the present investigation, in terms of species richness the group Chlorophyceae was the most dominant group. Rajagopalet. al, (2010) and Khan et. al, (2013) also reported dominancy of Chlorophyceae over other groups in their studied aquatic bodies.

Fig.1.2: -
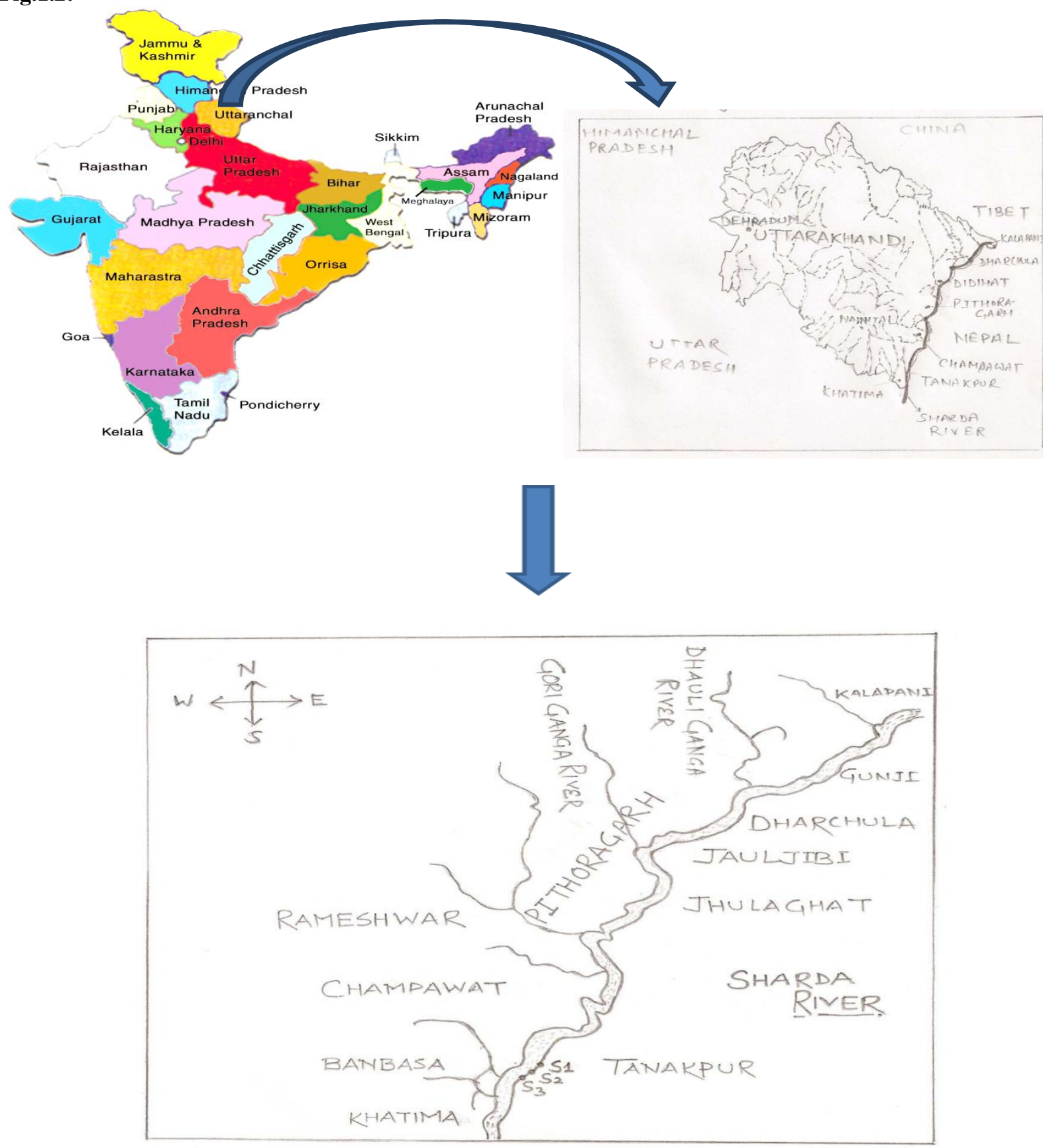

Above maps showing the river andsampling areas $\left(\mathrm{S}_{1-} 1^{\text {st }}\right.$ sampling site(Thuligad), $\mathrm{S}_{2}-2^{\text {nd }}$ sampling site (AdyaShaktipeeth-Boom temple) and $\mathrm{S}_{3}-3^{\text {rd }}$ sampling site (Hanuman Gari-Tanakpur town).

(Map is not to scale) 
Being the most important group in terms of percentage share of the phytoplankton standing crop, the abundance of Chlorophyceae varied from 83 units/litre (August) to 348 units/litre (April)(Table 1.3). The group Bacillariophyceae was the second dominant group and most of the constituting species of this group were intermittently present in the samples, while a few species namely Diatoma sp. and Synedra sp. were almost perennial in terms of occurrence. The population size of Bacillariophyceae varied from 53 (August) to 232 (April).In the present research, Bacillariophyceae was the second dominant group. Negi and Rajput, (2011) and Negi and Rajput, (2013) also reported the same results in their studies.

Cyanophyceae was the third important group in terms of percentage share to the total phytoplankton numbers. During the present study, the abundance of this group fluctuated between 50 (January) to 137 (April). Cyanophyceae was the third dominant group in terms of number of species contributed. Maximum number of Cyanophyceae taxa (3) were collected during March and August. Group Xanthophyceae shared least number of species in the phytoplankton community. It was represented by a single species during the whole study period. Being the least abundant group of phytoplankton community of Sharda River, the group Xanthophyceae was present only in the months of September and October.

The Shannon-Weiner information function of diversity and Simpson's dominance index both are quite significance functions of the community. In the present investigation the Shannon-Weiner diversity index ranged between 2.04 (July) and 2.613 (November) during entire study period. The values of diversity indices weregreater than 2 throughout the study period.The concentration of dominance showed a distinct inverse relation to that of species diversity index. During the whole study period in Sharda River, the dominance index ranged from 0.077 (December) to 0.134 (July).Shannon-Weiner diversity index and concentration of dominance depicted in fig 1.1. The range of seasonal variation in concentration of dominance was much narrow and, therefore, indicates that none of the phytoplankton taxa was exclusively dominant and distributed in this river.

\section{Conclusion: -}

Overall, the findings of the present study are hopeful to categorize the Sharda River as an unpolluted water body and the density of phytoplankton species is also sufficient for the maintenance of fish fauna in the river. None of the pollution tolerant species were over-dense in the river and, therefore, the river water is suitable for drinking water treatment plants. Further studies on the structure and organisation of phytoplankton community will be effective for water managers, governmental authorities, etc. towards its sustainable management and conservation for future perspective.

\section{Acknowledgement: -}

The author expresses profound gratitude to his parents and Head, Department of Zoology, R. H. Government P.G. College, Kashipur, Kumaun University, Uttarakhand, for laboratory facilities.

\section{References: -}

1. APHA (1999). Standard Methods for Examination of Water and Waste Water, $20^{\text {th }}$ ed., (APHA) American Public Health Association, New York.

2. Edmondson W. T. (1959). Freshwater Biology. John Willey and Sons. New York.

3. Desai S. R., SubashChandran M. D. and Ramachandra T. V., (2008). Phytoplankton diversity in Sharavati river basin, central Western Ghats, J. Soil and Wat. Sci., 1(1): 7-66.

4. Fitter R. and Manuel. (1986). Freshwater life of Britain and North West Europe. Willion Collins Sons \& Co. Ltd. London.

5. Huang L., Jian W., Song X., Huang X., Liu S., Qian P., Yin K. and Wu M. (2004). Species diversity and distribution for phytoplankton of the Pearl River estuary during rainy and dry seasons. Marine Pollution Bulletin. 49: 588-596.

6. Khan, Amir and Ishaq, Fouzia (2013); Comparative assessment of physico-chemicalconditions and Plankton diversity of River Tons and Asan in Dehradun District of Uttarakhand. Advances in Applied Science Research, 4(2): 342-355.

7. Lynch M. (1980). The evolution of cladoceran life histories. Q. Rev. Biol., 55: 23-42.

8. Negi, R.K. and Rajput, Anjana (2011); Diversity of phytoplankton in the fresh water streams of Kumaon Himalaya of Uttrakhand state. The ecoscan, An International quarterly journal of environmental science, $5(1 \&$ 2): $15-19$. 
9. Negi, R.K. and Rajput, Anjana (2013); Impact of Pulp and Paper Mill Effluents on Phytoplanktonic Community Structure in Ganga River at Bijnor (Up), India Journal of Entomology and Zoology Studies, 1(5): 70-73.

10. Pathani S. S., Upadhyay K. K. and Joshi S. K. (2002). Some physico-chemical parameters and primary productivity of river West Ramganga (Uttaranchal). Him. J. Env. Zool., 16(2): 151-158.

11. Pennak R. W. (1958). Freshwater Invertebrates of United States. $2^{\text {nd }}$ edition John Wiley \& Sons, New York.

12. Rajagopal, T., Thangamani A., and Archunan, G. (2010 b); Comparison of physico-chemical parameters and phytoplankton species diversity of two perennial ponds in Sattur area, Tamil Nadu, 31(5): 787-794.

13. Wetzel R. G. (1975). Limnology. W.B. Saunders Company, Philadelphia, USA, 743 pp.

14. Wetzel R. G. (2001). Limnology: Lake and River Ecosystems, Academic Press, San Diego, 1006 pp.

15. Zalocar de Domitrovic Y., Poi de Neifff ASG and Carso S. L. (2007). Abundance and diversity of phytoplankton in the Parana River (Argentina) 220 km downstream of the Yacyretá reservoir. Braz. J. Biol., 67(1): 53-63. 